\title{
KONTRIBUSI PENDAPATAN PEKERJA USAHA TAHU NIPON TERHADAP PENDAPATAN KELUARGA DI DESA TATELI KECAMATAN MANDOLANG KABUPATEN MINAHASA
}

\author{
Bima Satria Mohamad Noor \\ Elsje Pauline Manginsela \\ Welson Marthen Wangke
}

Naskah diterima melalui Website Jurnal Ilmiah agrisosioekonomi@unsrat.ac.id

\begin{abstract}
The purpose of this study was to determine the income contribution of Tahu Nipon Business workers to family income and the time allocation on Tahu Nipon Business workers. This research was conducted for three months, starting from January to March 2019. The data used in this study were primary data and secondary data. Primary data was obtained from direct interviews with workers and business owners of Tahu Nipon Business. Secondary data is obtained from the Office of The North Sulawesi Central Statistics Agency and Tateli Village Office; and the internet through google books and google scholarships to get journal articles and thesis related to the topic of this research, namely the contribution of workers 'income to family income and the outpouring of workers' time. The sampling method is a census with the number of respondents 6 workers. The results of this study indicated that the average income contribution of Tahu Nipon Business workers is $83.33 \%$ of family income. The average time spent by Tahu Nipon Workers in the research area in one day for domestic activities is 2.08 hours per day with a percentage of $8.66 \%$, while the time spent on productive activities is 8.33 hours per day with a percentage of $34.70 \%$, and time for other activities besides taking care of family and work, including sleep rest, averaging 13.5 hours per day with a percentage of $56.25 \%$. ${ }^{*}$ prm*
\end{abstract}

Keywords: income contribution, time aloocation, small-tofu industry, Tateli Village

\begin{abstract}
ABSTRAK
Tujuan penelitian ini adalah untuk mengetahui kontribusi pendapatan pekerja usaha Tahu Nipon terhadap pendapatan keluarga dan curahan waktu pekerja usaha Tahu Nipon. Penelitian ini dilaksanakan selama tiga bulan, mulai dari bulan Januari sampai Maret 2019. Data yang digunakan dalam penelitian ini adalah data primer dan data sekunder. Data primer diperoleh dari wawancara langsung kepada pekerja dan pemilik usaha Tahu Nipon. Data sekunder diperoleh dari Kantor Badan Pusat Statistik dan Kantor Desa; dan internet melalui google books dan google scholars untuk mendapatkan artikel jurnal dan skripsi yang berkaitan dengan topik penelitian ini yaitu kontribusi pendapatan pekerja terhadap pendapatan keluarga dan curahan waktu pekerja. Metode pengambilan sampel adalah sensus dengan jumlah responden 6 orang pekerja. Hasil dari penelitian ini menunjukkan rata-rata kontribusi pendapatan pekerja usaha Tahu Nipon sebesar $83,33 \%$ terhadap pendapatan keluarga. Rata-rata waktu yang dicurahkan pekerja Tahu Nipon di daerah penelitian dalam satu hari untuk kegiatan domestik adalah 2,08 jam per hari dengan persentase $8,66 \%$, sedangkan curahan waktu untuk kegiatan produktif adalah 8,33 jam per hari dengan persentase $34,70 \%$, dan waktu untuk aktifitas lain selain mengurus keluarga dan bekerja, termasuk istirahat tidur, rata-rata 13,5 jam per hari dengan persentase $56,25 \%$. ${ }^{*}$ erm $^{*}$
\end{abstract}

Kata kunci: Kontribusi pendapatan, Curahan waktu, Industri Kecil Tahu, Desa Tateli 


\section{PENDAHULUAN}

\section{Latar Belakang}

Tingginya laju pertumbuhan penduduk menyebabkan lapangan pekerjaan yang tersedia tidak mampu menampung secara penuh jumlah tenaga kerja yang ada. Upaya pemerintah dalam menangani masalah tersebut antara lain dengan menggalakkan berbagai jenis pengembangan usaha-usaha industri kecil, koperasi dan industri rumah tangga (Handayani dan Putu, 2009). Pembangunan ekonomi lebih mengarah kepada terciptanya struktur ekonomi yang seimbang yang di dalamnya terdapat kemampuan dan kekuatan industri yang maju. Oleh karena itu, dalam proses pembangunan nasional, industri mempunyai peranan yang sangat penting. Baik itu industri beskala besar, menengah maupun skala kecil/industri rumah tangga. Berdasarkan penelitian terdahulu menunjukkan bahwa industri kecil dapat meningkatkan pendapatan masyarakat serta menciptakan atau menjaga stabilitas ekonomi (Heldarina, 2015).

Menurut Budiarto (2015) peran usaha kecil (UMKM) sangat terlihat dari aspek-aspek antara lain peningkatan penyerapan tenaga kerja dan pemerataan pendapatan. Pekerja suatu industri/usaha kecil menggantungkan sebagian besar sumber pendapatan mereka dari usaha-usaha tersebut, sehingga dari situ diharapkan pendapatan dari pekerjaan mereka berpengaruh positif terhadap pertumbuhan ekonomi keluarga. Masyarakat sendiri juga semakin banyak yang berinisiatif membangun usaha berskala kecil demi mencukupi kebutuhan keluarga dan dalam waktu yang sama meningkatkan taraf hidup mereka. Jumlah penambahan sektor industri di Sulawesi Utara pada tahun 2017 tercatat sebesar 1.115 unit, dengan penambahan tenaga kerja sebesar 2.631 orang (BPS Provinsi Sulut, 2018).

Berdasarkan fenomena tersebut, maka dilakukan penelitian tentang Kontribusi Pendapatan Pekerja Usaha Tahu Nipon Terhadap Pendapatan Keluarga Di Desa Tateli Kecamatan Mandolang Kabupaten Minahasa. Usaha Tahu Nipon merupakan usaha yang tergolong skala kecil dengan jumlah pekerja sebanyak 6 orang, dimana hari kerja adalah setiap hari. Sebagian besar pekerja dari usaha Tahu Nipon sebagian besar berasal dari daerah Gorontalo yang tinggal di tempat yang sudah disediakan oleh pemilik usaha Tahu Nipon. Usaha ini telah berjalan selama lebih dari satu dekade sehingga telah dikenal masyarakat di Desa Tateli maupun Kota Manado pada umumnya.

\section{Rumusan Masalah Penelitian}

Berdasarkan latar belakang yang telah dikemukakan, maka yang menjadi permasalahan yang akan dikaji dalam penelitian ini adalah:

1. Seberapa besar kontribusi pendapatan pekerja terhadap pendapatan keluarga di usaha Tahu Nipon, Desa Tateli, Kecamatan Mandolang, Kabupaten Minahasa.

2. Bagaimana curahan waktu kerja pekerja usaha Tahu Nipon di Desa Tateli, Kecamatan Mandolang, Kabupaten Minahasa.

\section{Tujuan Penelitian}

Penelitian ini bertujuan untuk mengetahui:

1. Kontribusi pekerja usaha tahu Nipon terhadap pendapatan keluarga mereka.

2. Curahan waktu kerja pekerja usaha Tahu Nipon.

\section{Manfaat Penelitian}

Ada beberapa manfaat yang dapat diperoeh dari penulisan ilmiah ini, seperti:

1. Bagi peneliti, penelitian ini sebagai salah satu karya ilmiah untuk mengembangkan pengetahuan dan wawasan mengenai industri kecil pembuatan tahu.

2. Bagi pihak usaha Tahu Nipon, dapat menjadi bahan masukan maupun wawasan yang kiranya bisa bermanfaat dalam pengembangan usaha.

3. Bagi pembaca dan pihak lain, diharapkan dapat menambah wawasan dan pengetahuan seputar kontribusi pendapatan usaha kecil terhadap pertumbuhan ekonomi serta dapat memberikan informasi sebagai acuan untuk penelitian selanjutnya.

\section{METODE PENELITIAN}

\section{Lokasi dan Waktu Penelitian}

Penelitian ini dilaksanakan pada usaha Tahu Nipon yang berlokasi di Desa Tateli Kecamatan Mandolang Kabupaten Minahasa. Penelitian ini berlangsung selama 3 bulan yang dimulai dari bulan Januari 2019 sampai dengan bulan Maret 2019. 


\section{Metode Pengumpulan Data}

Penelitian ini menggunakan 2 jenis data yaitu Data Primer dan Sekunder. Data Primer diperoleh dari wawancara secara langsung pada pekerja serta pemilik usaha pembuatan Tahu Nipon. Instrumen penelitian yang digunakan untuk memudahkan proses pengambilan data yaitu dengan menggunakan Kuesioner atau daftar pertanyaan yang telah disusun sesuai kebutuhan peneliti. Data Sekunder adalah suatu data yang berasal dari tangan kedua, tangan ketiga dan seterusnya, yang artinya melewati satu atau lebih pihak yang bukan berasal dari peneliti itu sendiri. Teknik pengambilan data sekunder adalah dengan Dokumentasi yang berbentuk catatan-catatan maupun data-data berbentuk tulisan yang berhubungan dengan penelitian. Adapun data sekunder yang diperoleh yaitu dari Badan Pusat Statistik (BPS), Provinsi Sulawesi Utara, Data Monografi Desa Tateli serta telaah pustaka yang berkaitan dengan penelitian ini.

\section{Populasi dan Sampel}

Metode pengambilan sampel dilakukan dengan sensus dan mengambil seluruh populasi pekerja usaha Tahu Nipon di Desa Tateli. Jumlah sampel sebagai responden yaitu 6 orang pekerja.

\section{Konsep Pengukuran Variabel}

Variabel yang diukur dalam penelitian ini adalah:

a. Karakteristik responden, yang meliputi umur pekerja (tahun), tingkat pendidikan (SD, SMP, SMA/SMK), status dalam rumah tangga (Kepala keluarga, Ayah, Ibu, Isteri dan Anak) dan jumlah anggota keluarga (orang).

b. Upah pekerja usaha tahu Nipon (Rp/bulan).

c. Pendapatan anggota keluarga pekerja usaha tahu yang terbagi atas

-Pendapatan pekerja usaha Tahu Nipon (Rp/bulan)

-Pendapatan anggota keluarga yang tidak bekerja di usaha Tahu Nipon yang termasuk Isteri, Ibu dan tanggungan keluarga lainnya (Rp/bulan) d. Alasan bekerja, yaitu dorongan yang timbul untuk bekerja di usaha Tahu Nipon.

e. Kontribusi pendapatan pekerja Tahu Nipon terhadap pendapatan keluarga dalam persentase (\%).

f. Curahan waktu pekerja Tahu Nipon (jam)

\section{Metode Analisis Data}

Penelitian ini menggunakan pendekataan yang lebih dominan pada pendekatan kualitatif tetapi dilengkapi juga dengan data kuantitatif sesuai dengan tujuan penelitian. Pendekatan kualitatif digunakan dengan maksud mendeskripsikan, menguraikan dan menggambarkan data secara mendalam tentang karakteristik responden, curahan waktu serta kontribusi pendapatan pekerja usaha Tahu Nipon terhadap pendapatan keluarga.

Analisis data yang digunakan dalam penelitian ini adalah Analisis Data Kontribusi, yaitu analisa yang digunakan untuk mengetahui seberapa besar kontribusi pekerja usaha Tahu Nipon terhadap pendapatan keluarga per bulan dalam persentase.

Untuk mengetahui besarnya kontribusi pekerja tahu Nipon terhadap pendapatan keluarga digunakan rumus:

Kontribusi $=\frac{\mathrm{X}_{1}}{\mathrm{X}_{2}} \times 100 \% \ldots \ldots . .($ Zulfikri et al, 2014) Dimana:

$\mathrm{X}_{1} \quad=$ Pendapatan pekerja usaha Tahu Nipon

$\mathrm{X}_{2} \quad=$ Total Pendapatan keluarga

Kontribusi pekerja usaha tahu

$=\frac{\text { Pendapatan pekerja usaha tahu }}{\text { Total pendapatan keluarga }} \times 100 \%$

Kontribusi pekerja usaha tahu $=$ (Pendapatan pekerja usaha tahu)/(Total pendapatan keluarga) x $100 \%$

Adapun besarnya pendapatan keluarga diperoleh dari Rumus:

Pendapatan keluarga $=$ Pendapatan suami/pekerja

Usaha Tahu Nipon + pendapatan isteri/ibu + pendapatan anggota keluarga lain 


\section{HASIL DAN PEMBAHASAN}

\section{Profil Usaha Tahu Nipon}

Usaha Tahu Nipon merupakan usaha kecil yang bergerak di industri pengolahan pangan. Usaha ini didirikan pada tahun 2011 oleh Bapak Natanael Nurhaenis dan Ibu Erni Pondaag. Usaha Tahu Nipon terletak di Desa Tateli Kecamatan Mandolang Kabupaten Minahasa. Usaha ini memproduksi produk olahan kedelai yaitu berupa Tahu. Usaha ini memiliki jumlah tenaga kerja sebanyak 6 orang dengan upah perbulan Rp. 2.500.000/org. Usaha Tahu Nipon mempunyai hari kerja setiap hari dimulai dari jam 07.0016.00 WITA dengan jumlah produksi per harinya rata-rata sebesar $400 \mathrm{Kg}$. Daerah pemasaran Usaha Tahu Nipon yaitu di daerah Manado, tepatnya Pasar Bersehati, Sangihe Talaud serta sekitar Desa Tateli dan Kalasey. Pemasaran produk Tahu ini dilakukan dengan cara produk dijual langsung ke pasar, dan dikirim setelah pemesanan untuk daerah Sangihe Talaud serta pembeli bisa datang langsung ke pabrik (Sumber: Hasil wawancara dengan pemilik Usaha Tahu Nipon pada tanggal 12 Februari 2019).

\section{Deskripsi Umum Daerah Penelitian Kondisi Geografis Daerah Penelitian}

Desa Tateli merupakan sebuah kelurahan yang terletak di Kecamatan Mandolang, Kabupaten Minahasa dengan luas wilayah 170 Ha. Secara geografis, Desa Tateli dibatasi oleh:
a. Sebelah Utara : Pantai Mandolang
b. Sebelah Selatan: Desa Koha
c. Sebelah Barat : Desa Tateli Weru
d. Sebelah Timur : Desa Tateli Timur

Desa Tateli terbagi menjadi 5 wilayah jaga. Perangkat desa di Desa Tateli terdiri dari seorang Kepala Desa (Kades), 1 orang Sekretaris desa, 3 orang kepala Seksi, 2 orang kepala Urusan, dan 5 orang kepala Dusun.

\section{Kondisi Demografi di Desa Tateli}

Secara demografis jumlah kepala keluarga di Desa Tateli adalah $343 \mathrm{KK}$ yang terdiri dari 1.296 jiwa dengan rata-rata 3,78 anggota keluarga per KK . Penduduk Desa Tateli berjumlah 1.296 jiwa, yang terdiri dari laki-laki 651 jiwa dan perempuan 645 jiwa.

\section{Karakteristik Responden}

Karakteristik responden yang dimaksud disini ialah umur responden, tingkat pendidikan, alasan bekerja, status dalam keluarga dan jumlah tanggungan keluarga dari pekerja usaha Tahu Nipon.

\begin{tabular}{llccc}
\hline \multicolumn{6}{l}{ Tabel 4. Karakteristik Responden } \\
No & \multicolumn{1}{c}{ Uraian } & Satuan & Range & $\begin{array}{c}\text { Rata- } \\
\text { rata }\end{array}$ \\
\hline 1. & Umur & Tahun & $25-34$ & 28 \\
2. & Jumlah anggota & Orang & $1-3$ & 1,67 \\
& keluarga & Tahun & $6-12$ & 10,5 \\
\hline Sumber: & Pata Primer, diolah dari lampiran 1
\end{tabular}

\section{Jumlah Anggota Keluarga}

Jumlah anggota keluarga merupakan banyaknya jiwa yang tinggal dalam satu atap dan makan dalam satu dapur yang meliputi suami, isteri, anak dan anggota keluarga lain yang menjadi beban tanggungan dalam keluarga. Jumlah anggota keluarga yang besar akan membuat beban tanggungan kepala rumah tangga semakin berat, apalagi anggota rumah tangga tersebut berumur nonproduktif.

Jumlah anggota keluarga merupakan banyaknya jiwa yang tinggal dalam satu atap dan makan dalam satu dapur yang meliputi suami, isteri, anak dan anggota keluarga lain yang menjadi beban tanggungan dalam keluarga. Jumlah anggota keluarga yang besar akan membuat beban tanggungan kepala rumah tangga semakin berat, apalagi anggota rumah tangga tersebut berumur nonproduktif. Tabel 4 memperlihatkan bahwa jumlah anggota keluarga responden berkisar antara 1-3 orang dengan rataan 1,67 orang.

\section{Tingkat Pendidikan}

Pendidikan merupakan salah satu faktor untuk mengetahui kualitas daya manusia dan turut menentukan tingkat produktivitas seseorang. Makin lama pendidikan seseorang makin baik kualitas kerjanya.

Pekerja usaha Tahu Nipon tidak dituntut berpendidikan formal tinggi dan terlihat dari Tabel 4 bahwa lama pendidikan yang ditempuh oleh pekerja usaha Tahu Nipon berkisar antara 6-12 tahun, dengan rataan 10,5 tahun. Hal ini menunjukkan pekerja usaha Tahu Nipon sebagian besar sudah memiliki tingkat pendidikan yang baik, yaitu diatas 10 tahun atau setara tingkat SMA/SMK. 


\section{Alasan Bekerja}

Tabel 6 menunjukkan bahwa responden yang memiliki alasan bekerja di usaha Tahu Nipon karena ingin mandiri atau memperoleh penghasilan sendiri sebanyak 1 orang $(16,67 \%)$, kemudian responden dengan alasan tidak punya pilihan pekerjaan lain sebanyak 2 orang $(33,33 \%)$. 2 orang responden $(33,33 \%)$ memilih bekerja di usaha Tahu Nipon karena ingin membantu penghasilan keluarga di Gorontalo. Sisanya yaitu 1 orang pekerja $(16,67 \%)$ memilih bekerja karena alasan lebih baik bekerja daripada menganggur.

\begin{tabular}{|c|c|c|c|}
\hline \multirow{2}{*}{ No } & \multirow{2}{*}{ Alasan } & \multicolumn{2}{|c|}{ Total } \\
\hline & & $\mathrm{N}$ & $\%$ \\
\hline 1. & Ingin mandiri & 1 & 20,00 \\
\hline 2. & $\begin{array}{l}\text { Tidak punya pilihan pekerjaan } \\
\text { lain }\end{array}$ & 2 & 40,00 \\
\hline 3. & $\begin{array}{l}\text { Membantu penghasilan } \\
\text { keluarga }\end{array}$ & 1 & 20,00 \\
\hline 4. & $\begin{array}{l}\text { Lebih baik bekerja daripada } \\
\text { menganggur }\end{array}$ & 1 & 20,00 \\
\hline & Jumlah & 5 & 100,00 \\
\hline
\end{tabular}

\section{Status Dalam Keluarga}

Dalam memasuki sebuah keluarga, seseorang diwarisi suatu rangkaian status. Seseorang menerima beberapa status dalam keluarga berdasarkan umur, jenis kelamin, urutan kelahiran dan lainnya (Supriatna, 2006).

Responden yang diteliti ada yang sudah berkeluarga dan berstatus sebagai Suami atau kepala keluarga, berjumlah 2 orang pekerja. Ada pula 1 orang pekerja yang belum berkeluarga dan berstatus sebagai Anak yang tinggal satu atap dengan Ibu kandung. Terdapat 3 orang pekerja yang belum berkeluarga atau bujang.

\section{Pekerjaan Anggota Keluarga Responden}

Anggota keluarga dari pekerja Tahu Nipon memperoleh penghasilan dari bekerja di pabrik pembuatan Tempe dan Tahu Nipon itu sendiri. Pekerjaan anggota keluarga responden dapat dilihat di Tabel 7.

Tabel 7. Distribusi Anggota Keluarga Responden menurut Pekerjaan

\begin{tabular}{cccc}
\hline \multicolumn{3}{c}{ Pekerjaan } & Jumlah \\
No. & Pekerjaan & Persentase (\%) & \\
\hline 1. & IRT & 1 & 25,00 \\
2. & $\begin{array}{c}\text { Pekerja pabrik } \\
\text { Tempe } \\
\text { Pekerja Tahu } \\
\text { Nipon }\end{array}$ & 2 & 50,00 \\
\hline & 1 & 25,00 \\
\hline
\end{tabular}

Pada Tabel 7 dapat dilihat bahwa sebagian besar anggota keluarga responden ikut serta dalam memberikan sumbangan penghasilan terhadap pendapatan keluarga dengan bekerja sebagai buruh pabrik tempe berjumlah 2 orang $(66,67 \%)$ sedangkan 1 orang $(33,33 \%)$ anggota keluarga bekerja sebagai Ibu Rumah Tangga (IRT).

\section{Hasil Penelitian \\ Rata-rata Pendapatan Responden}

Pendapatan pekerja adalah pendapatan yang diterima langsung setelah bekerja. Pendapatan ini adalah pendapatan bersih yang sudah dikurangi dengan biaya yang dikeluarkan selama bekerja. Dari hasil data pendapatan pekerja usaha Tahu Nipon bisa dilihat total pendapatan dari 5 orang pekerja setiap bulan sebesar Rp12.500.000,-per bulan dengan ratarata setiap responden adalah Rp. 2.500.000,- /bulan. Pendapatan ini relatif kecil atau kurang dari UMP yang telah ditetapkan Provinsi Sulawesi Utara namun pekerja tetap memilih bekerja sebagai buruh karena berbagai alasan seperti ingin mandiri dan tidak memiliki pilihan pekerjaan lain. Ada juga salah satu pekerja usaha Tahu Nipon yang menganggap lebih baik bekerja dengan upah rendah daripada tidak bekerja sama sekali agar dapat memberikan kontribusi bagi pendapatan keluarga.

\section{Rata-rata Pendapatan Anggota Keluarga Responden}

Tabel 8. Pendapatan Rata-rata Anggota Keluarga Responden Pekerja Tahu Nipon dalam Rp/bulan

\begin{tabular}{|c|c|c|c|c|}
\hline \multirow{2}{*}{$\begin{array}{l}\text { No. } \\
\text { Resp. }\end{array}$} & \multirow{2}{*}{$\begin{array}{l}\text { Pendapatan } \\
\text { Responden } \\
\text { (Rp/bulan) }\end{array}$} & \multicolumn{2}{|c|}{ Pendapatan Non-responden } & \multirow{2}{*}{$\begin{array}{c}\text { Jumlah } \\
\text { pendapatan } \\
\text { rumah } \\
\text { tangga } \\
\end{array}$} \\
\hline & & $\begin{array}{c}\text { Isteri } \\
\text { (Rp/bulan) }\end{array}$ & $\begin{array}{c}\text { Ibu } \\
\text { (Rp/bulan) }\end{array}$ & \\
\hline 1 & $2,500,000$ & 0 & 0 & $2,500,000$ \\
\hline 2 & $2,500,000$ & 0 & 0 & $2,500,000$ \\
\hline 3 & $2,500,000$ & 0 & $1,500,000$ & $4,000,000$ \\
\hline 4 & $2,500,000$ & 0 & 0 & $2,000,000$ \\
\hline 5 & $2,500,000$ & 0 & 0 & $2,500,000$ \\
\hline 6 & $2,500,000$ & $1,500,000$ & 0 & $4,000,000$ \\
\hline Total & $15,000,000$ & $1,500,000$ & $1,500,000$ & $18,000,000$ \\
\hline $\begin{array}{c}\text { Rata- } \\
\text { rata }\end{array}$ & $2,500,000$ & 250,000 & 250,000 & $3,000,000$ \\
\hline
\end{tabular}

Sumber: Data Primer, diolah pada tahun 2019

Berdasarkan Tabel 8 dapat dijelaskan bahwa pendapatan dari masing-masing anggota keluarga (termasuk responden) dihitung dalam Rp/bulan. Pendapatan tertinggi didapat dari pekerja Tahu Nipon dengan rata-rata pendapatan sebesar Rp. 2.500.000,- per bulan. Pendapatan dari anggota keluarga lain yaitu Isteri dan dari responden, memiliki nilai rata-rata yang lebih rendah. 
Dari hasil wawancara, diketahui bahwa usaha Tahu Nipon menanggung biaya akomodasi serta konsumsi makanan bagi pekerja yang tinggal di mess pabrik Tahu dimana terdapat 5 responden yang tinggal di mess pabrik, sehingga meskipun pendapatan yang diperoleh masih dibawah UMP Provinsi Sulawesi Utara, namun pengeluaran hidup yang dimiliki tidak terlalu besar.

\section{Curahan Waktu Kerja Responden}

Berdasarkan hasil wawancara dan penjelasan pada Tabel 9, dapat dilihat bahwa dari setiap jenis kegiatan responden terdapat variasi dari segi curahan waktu. Curahan waktu responden dapat diklasifikasikan menjadi:

A. Kegiatan domestik (Rumah tangga), yaitu seluruh kegiatan yang dilakukan responden berkaitan dengan pemeliharaan rumah tangga dan keluarga yang mencakup memasak, mencuci, membersihkan tempat tinggal, hingga pengasuhan anak. Rata-rata curahan waktu yang dicurahkan responden dalam kegiatan domestik adalah 2,08 jam dalam satu hari dengan persentase $8,66 \%$.

B. Kegiatan produktif (mencari nafkah), yaitu kegiatan yang berkaitan dengan pencarian nafkah, dalam hal ini seluruh responden bekerja pada usaha Tahu Nipon mencurahkan rata-rata waktu sebesar 8,33 jam dalam satu hari dengan persentase $34,70 \%$.

C. Kegiatan lain, yaitu aktivitas yang dilakukan diluar jam kerja dan mengurus rumah tangga. Kegiatan yang dilakukan berupa menonton TV, menelpon keluarga, mendengarkan musik, pergi sholat, serta istirahat malam. Rata-rata curahan waktu responden untuk aktivitas lain adalah 13,5 jam per hari dengan persentase $56,25 \%$.
Tabel 9. Rata-rata Curahan Waktu Responden Dalam Keluarga (jam/hari)

\begin{tabular}{|c|c|c|c|c|}
\hline \multirow[b]{2}{*}{$\begin{array}{l}\text { No } \\
\text { resp. }\end{array}$} & \multicolumn{3}{|c|}{ Curahan Waktu Responden } & \multirow[b]{2}{*}{$\begin{array}{l}\text { Jumlah } \\
\text { (Nilai/\%) }\end{array}$} \\
\hline & $\begin{array}{c}\text { Kegiatan } \\
\text { Domestik } \\
\text { (rumah } \\
\text { tangga) } \\
(\text { jam/\%) }\end{array}$ & $\begin{array}{l}\text { Kegiatan } \\
\text { produktif } \\
\text { (mencari } \\
\text { nafkah) } \\
(\mathrm{jam} / \%)\end{array}$ & $\begin{array}{c}\text { Aktivitas } \\
\text { lain } \\
(\text { jam\%) }\end{array}$ & \\
\hline 1 & $2(8,33)$ & $8 \quad(33.33)$ & $\begin{array}{l}14 \\
(58,33)\end{array}$ & $24(100)$ \\
\hline 2 & $2 \quad(8,33)$ & $8 \quad(33.33)$ & $\begin{array}{l}13,5 \\
(56,25)\end{array}$ & $24(100)$ \\
\hline 3 & $1,5(6,25)$ & $8 \quad(33.33)$ & $\begin{array}{l}14,5 \\
(60,42)\end{array}$ & $24(100)$ \\
\hline 4 & $2,5(10,42)$ & $8 \quad(33.33)$ & $\begin{array}{l}13,5 \\
(56,25)\end{array}$ & $24(100)$ \\
\hline 5 & $2,5(10,42)$ & $8(33,33)$ & $\begin{array}{l}13,5 \\
(56,25)\end{array}$ & $24(100)$ \\
\hline 6 & $2 \quad(8,33)$ & $10(41,67)$ & $\begin{array}{l}12 \\
(50,00)\end{array}$ & $24(100)$ \\
\hline Total & $\begin{array}{l}12,5 \\
(52,083) \\
\end{array}$ & $50(208,33)$ & $\begin{array}{l}81 \\
(337,5) \\
\end{array}$ & \\
\hline $\begin{array}{c}\text { Rata- } \\
\text { rata }\end{array}$ & $2,08(8,66)$ & $8,33(34,70)$ & $\begin{array}{l}13,5 \\
(56,25)\end{array}$ & $24(100)$ \\
\hline
\end{tabular}

\section{Kontribusi Pendapatan Pekerja Usaha Tahu Nipon Terhadap Pendapatan Keluarga}

Kontribusi yang dimaksud dalam penelitian ini adalah sumbangan dari pekerja usaha Tahu Nipon sebanyak 6 responden. Menurut hasil wawancara, para pekerja usaha Tahu Nipon memperoleh pendapatan seluruhnya hanya dari bekerja di pabrik tahu dan tidak mengusahakan pekerjaan lain. Hal ini diduga dipengaruhi oleh curahan waktu yang besar di pabrik sehingga pekerja merasa tidak memiliki waktu luang untuk mencari penghasilan dari pekerjaan lain.

Untuk mengetahui besar nilai kontribusi pendapatan pekerja usaha Tahu Nipon terhadap pendapatan keluarga digunakan perhitungan sebagai berikut:

Kontribusi $=\frac{\mathrm{x}_{1}}{\mathrm{X}_{2}} \times 100 \%$ (Zulfikri, 2014)

Dimana:

$\mathrm{X}_{1}=$ Total pendapatan responden selama satu bulan

$\mathrm{X}_{2}=$ Total pendapatan anggota keluarga (termasuk responden) selama satu bulan

Rata-rata kontribusi $=\frac{2,500,000}{3,000,000} \times 100 \%=$ $83,33 \%$ 
Tabel 10. Kontribusi Pendapatan Pekerja Usaha Tahu Nipon

\begin{tabular}{lccc}
\multicolumn{3}{c}{ Terhadap Pendapatan Keluarga } \\
\hline $\begin{array}{c}\text { Anggota } \\
\text { Rumah } \\
\text { Tangga }\end{array}$ & $\begin{array}{c}\text { Total } \\
\text { Pendapatan } \\
\text { (Rp/Bulan) }\end{array}$ & Rata-rata & $\begin{array}{c}\text { Kontribusi } \\
(\%)\end{array}$ \\
\hline $\begin{array}{l}\text { Suami } \\
\text { (Pekerja }\end{array}$ & $12,500,000$ & $2,500,000$ & 69,44 \\
tahu) & & \\
$\begin{array}{l}\text { Anggota } \\
\text { keluarga } \\
\text { lain }\end{array}$ & $3,000,000$ & 600,000 & \\
\hline Jumlah & $\mathbf{1 8 , 0 0 0 , 0 0 0}$ & $\mathbf{3 , 6 0 0 , 0 0 0}$ & $\mathbf{1 0 0}$ \\
\hline
\end{tabular}

Sumber: Data Primer, diolah pada tahun 2019

Dari Tabel 10 dapat dilihat bahwa total pendapatan responden dan pendapatan keluarga maka rata-rata kontribusi pendapatan pekerja usaha Tahu Nipon seluruhnya terhadap pendapatan keluarga adalah 83,33\%. Mengikuti kriteria penilaian Kontribusi dari Zulfikri, dkk (2014), maka dirasa perlu untuk membuat perubahan pada kategori penilaian kontribusi menjadi:

Tabel 11. Kriteria Kontribusi Pendapatan

\begin{tabular}{cc}
\hline $\begin{array}{c}\text { Persentase Tingkat } \\
\text { Kontribusi }\end{array}$ & Kriteria Kontribusi \\
\hline $0,00-10,00 \%$ & Sangat kecil \\
$10,01-20,00 \%$ & Kecil \\
$20,01-30,00 \%$ & Sedang \\
$30,01-40,00 \%$ & Cukup \\
$41,01-50,00 \%$ & Besar \\
$>50 \%$ & Sangat besar \\
\hline
\end{tabular}

Berdasarkan kriteria penilaian di Tabel 11, maka kontribusi pendapatan pekerja Tahu Nipon terhadap pendapatan keluarga dikategorikan sangat besar karena nilainya $>50 \%$.

Sedangkan itu, dapat dilihat pula kontribusi anggota keluarga lain responden dari total pendapatan Rp. 3,000,000,- dengan rata-rata Rp. 500,000,- diperoleh nilai kontribusi sebesar $16,67 \%$ yang artinya lebih rendah dari kontribusi pekerja Tahu Nipon serta dikategorikan kecil karena nilainya berada di range 10,01 - 20,00\%. Nilai kontribusi yang besar dari pekerja Tahu dipengaruhi oleh status sebagian pekerja yang masih bujang atau menanggung beban diri sendiri, sehingga total pendapatan keluarga hanya berasal dari responden.

Dari hasil wawancara diketahui bahwa 5 orang responden, baik yang masih bujang maupun sudah menikah, mengirim uang ke keluarga mereka di Gorontalo secara rutin. Ada yang mengirim sebulan sekali sebanyak $1 / 5$ dari pendapatan, ada yang mengirim tiga bulan sekali sebanyak Rp. 4,000,000,-- sampai Rp. 5,000,000,-. Sedangkan 3 orang pekerja yang menanggung beban diri sendiri juga mengirim uang 5 bulan sekali sebanyak Rp. 4,000,000,- sampai Rp. $5,000,000,-$ dan 3 bulan sekali dengan jumlah Rp. 4,000,000,-.

Diketahui juga dari hasil wawancara bahwa jika ada keperluan mendadak dari keluarga mereka, maka mereka mengirim seluruh pendapatan dari pekerjaan di Tahu Nipon. Pekerja mengirimkan uang untuk berbagai keperluan terhadap keluarga mereka di Gorontalo karena alasan ingin membantu orang tua atau keluarga. Ada yang untuk memenuhi kebutuhan sehari-hari dan ada juga yang sedang membangun rumah di Gorontalo sehingga pendapatan dari bekerja di usaha Tahu Nipon sangat membantu dalam merealisasikan hal tersebut.

\section{KESIMPULAN DAN SARAN}

\section{Kesimpulan}

Hasil yang ditemukan dilapangan menunjukkan kontribusi pendapatan pekerja usaha Tahu Nipon adalah sebesar 83,33\% terhadap pendapatan keluarga. Nilai $83,33 \%$ menurut Zulfikri, dkk (2014) dalam kriteriapenilaian kontribusi tergolong dalam kategori sangat besar (>50\%) yang artinya dengan pendapatan yang diperoleh pekerja sebagai buruh usaha Tahu Nipon sangat membantu keluarga maupun diri sendiri dalam memenuhi dan mencukupkan kebetuhan setiap hari dan memberikan kontribusi yang nyata terhadap pendapatan keluarga. Sehingga bila tanpa kontribusi dari responden, maka kebutuhan dalam keluarga belum dapat tercukupi.

Rata-rata waktu yang dicurahkan pekerja Tahu Nipon di daerah penelitian dalam satu hari untuk kegiatan domestik (rumah tangga) adalah 2,08 jam per hari dengan persentase $8,66 \%$, sedangkan curahan waktu untuk kegiatan produktif adalah 8,33 jam per hari dengan persentase $34,70 \%$, dan waktu untuk aktifitas lain selain mengurus keluarga dan bekerja ratarata 13,5 jam per hari dengan persentase $56,25 \%$. 


\section{Saran}

Untuk meningkatkan kontribusi dalam pendapatan keluarga sebaiknya pekerja bisa lebih memanfaatkan waktu luang ketika tidak melakukan pekerjaan sebagai buruh usaha Tahu Nipon dengan melakukan kegiatan atau usaha yang lain agar bisa menambah pendapatan. Selain itu upah pekerja Tahu Nipon yang masih dibawah UMP Provinsi Sulawesi Utara perlu ditinjau kembali oleh pemilik usaha Tahu Nipon, mengingat curahan waktu dan tenaga yang harus diberikan pekerja sangat tinggi tentu belum sebanding dengan penghasilan yang diperoleh.

\section{DAFTAR PUSTAKA}

Budiarto R, dkk. 2015. Pengembangan UMKM: Antara Konseptual dan Pengalaman.

Handayani, M, Th. Dan Putu A. N. W. 2009. Kontribusi Pendapatan Ibu Rumah.

Heldarina. 2015. Kontribusi Pekerja Perempuan Terhadap Pendapatan Keluarga Pada.

Zulfikri., Dolorosa E., dan Komariyati. 2014. Analisis Kontribusi Usaha Ternak Sapi Potong Terhadap Pendapatan Rumah Tangga Petani di Kecamatan Tebas Kabupaten Sambas. Skripsi Fakultas Pertanian Universitas Tanjungpura. 